\title{
FAKTOR-FAKTOR YANG MEMPENGARUHI RENDAHNYA CAKUPAN ASI EKSKLUSIF PADA BAYI UMUR 0-6 BULAN DI BIDAN PRAKTIK SALASIAH GUN KECAMATAN PALARANSAMARINDA TAHUN 2017
}

\author{
Nuuva Yusuf ${ }^{1}$, Herni Johan ${ }^{2}$, Rizky Diah Anggrainii ${ }^{3}$ \\ ${ }^{1,2,3}$ Akademi Kebidanan Mutiara Mahakam
}

\begin{abstract}
Abstrak
Angka kematian bayi yang cukup tinggi didunia dapat dihindari dengan pemberian air susu ibu, pemberian ASI semaksimal mungkin merupakan kegiatan yang berperan penting dalam pemeliharaan anak dan persiapan generasi penerus dimasa depan. Banyaknya bayi yang tidak mendapatkan ASI Eksklusif disebabkan oleh karakteristik ibu diantaranya umur ibu yang terlalu muda sehingga tidak mengerti akan kebutuhan bayi, Pendidikan yang tidak memadai, pertama kali melahirkan sehingga tidak tahu pentingnya ASI Eksklusif, Pekerjaan, Mementingkan keindahan tubuh pasca persalinan, atau juga bisa disebabkan oleh kurangnya pengetahuan ibu disebabkan ibu tidak mendapatkan informasi dari pihak kesehatan, keluarga dan masyarakat. Penelitian ini bertujuan untuk mengetahui faktor -faktor yang mempengaruhi rendahnya cakupan ASI Eksklusif pada bayi umur 0-6 bulan di Bidan Praktik Salasiah Gun.

Metode atau teknik sampling yang digunakan dalam penelitian ini adalah Non Probability sampling tipe (quota sampling). Tehnik Quota Sampling yaitu pengambilan sampel secara quota dilakukan dengan cara menetapkan sejumlah anggota sampel secara quotum atau jatah. Dalam menentukan besarnya sampel, apabila subjek penelitian kurang dari 100, lebih baik diambil semua sehingga penelitiannya merupakan penelitian populasi. Selanjutnya, jika jumlah subjeknya besar dapat diambil antara $10-15 \%$ atau $20-25 \%$ atau lebih. Dalam hal ini peneliti mengambil sampel $20 \%$ dari populasi yang ada. Sehingga dapat diketahui jumlah sampel adalah 195 orang X 20\% = 39 orang.

Berdasarkan hasil penelitian yang telah dilakukan terhadap faktor - faktor yang mempengaruhi rendahnya cakupan ASI Eksklusif pada bayi umur 0-6 bulan di Bidan Praktik Salasiah Gun. Didapatkan kesimpulan bahwapengetahuan ibu terhadap pemberian ASI Eksklusif masih kurang.
\end{abstract}

Kata Kunci: ASI eksklusif, bayi baru lahir 


\begin{abstract}
Numbers of infant mortality can be prevented by supplying breast milk to the newborn infant. This has a big role in mothering child for the future good. Lack of awareness of mother in giving exclusive breast milk to her babies is caused by certain factor which is the characteristic of mothers such as immature mother who lack of understanding how to nursing infant, lack of nursing education, first experience of giving birth, job, body treatment after giving birth, and unavailability of health information from the officials, and relatives.

This research aimed to discever factors that affected the deficient of breast milk for 0-6 months infant in Salsaliah Gun Clinic Palaran Samarinda City 2017.

The methode used in this research is non-probability sampling type (quote sampling). Quote sampling is collecting samples by quote conducted by determining numbers of samples group. In determining the amount of samples, if the subject less than 100, the samples are taken entirely, thus become population research. On the contrary, if the samples reaches between 10-15\% or 20$25 \%$ or more, in this case, $20 \%$ are obtained from the entire population. The result of samples are 195 people $\times 20 \%=39$ subjects.

Based on the conclusion of this research, lack of breast milk supply for the 0-6 months infant at Salsaliah Gun Clinic Palaran Samarinda City 2017 concluded that the knowledge about breast milk for infant are still low.
\end{abstract}

Keywords: ASI eksklusif, bayi baru lahir

\section{PENDAHULUAN}

Angka kematian bayi yang cukup tinggi didunia dapat dihindari dengan pemberian air susu ibu, pemberian ASI semaksimal mungkin merupakan kegiatan yang berperan penting dalam pemeliharaan anak dan persiapan generasi penerus dimasa depan (Arifin, 2004).

Menurut WHO/UNICEF (World Health Organization/United Nations Children's Fund) tahun 2003, 60\% kematian balita secara langsung maupun tidak langsung disebabkan karena kurang gizi dan 2/3 dari kematian tersebut terkait dengan praktik pemberian makanan yang terlalu dini pada bayi (Depkes RI, 2007).

Berdasarkan Data Survei Sosial Ekonomi Nasional (Susenas) pada tahun 2005 dan 2006 telah terjadi peningkatan cakupan pemberian ASI eksklusif dari 49,0\% pada tahun 2005 menjadi $58,5 \%$ pada tahun
2006. Sebagaimana diketahui, pemerintah menetapkan target cakupan pemberian ASI eksklusif pada tahun 2010 sebesar $80 \%$. Upaya peningkatan pemberian ASI eksklusif perlu dilanjutkan dan terus ditingkatkan (Depkes RI, 2007).

Di Indonesia, Berdasarkan Data Survei Sosial Ekonomi Nasional (SUSENAS) pada tahun 2007 dan 2008 cakupan pemberian ASI eksklusif menunjukkan penurunan dari 62,2\% menjadi 56,2\% (Depkes RI, 2010).

Data Dinas Kesehatan Provinsi Kalimantan Timur pada tahun 2010 terdapat jumlah bayi umur 0-6 bulan 42.790 dan bayi yang mendapatkan ASI Eksklusif 9.588 $(22,41 \%)$ dari 13 kota/kabupaten (Dinas Kesehatan Kabupaten/Kota, 2010).

Data Dinas Kesehatan Kota Samarinda pada tahun 2010 terdapat jumlah bayi umur 0-6 bulan 9.194 dan bayi yang mendapatkan ASI Eksklusif $4.362(47,44 \%)$ dari 8 
Kecamatan yang terdapat di Samarinda (Bid.

Kesga dan Pemberdayaan Masyarakat, 2010).

Data dari Puskesmas Palaran pada tahun 2010 terdapat jumlah bayi pada umur 0-6 bulan yaitu 404 dari 5 kelurahan yang ada. Sedangkan bayi yang mendapatkan ASI Eksklusif yaitu 148 (36,63\%).

Data dari Bidan Praktik Salasiah Gun terdapat jumlah bayi umur 0-6 bulan 195 dan bayi yang mendapatkan ASI Eksklusif 50 $(25,64 \%)$ pada bulan Juli sampai Desember 2010.

Berdasarkan studi pendahuluan di Bidan Praktik Salasiah Gun dari 10 responden yang diteliti didapatkan 5 responden saja yang mengerti tentang pemberian ASI Eksklusif.

Banyaknya bayi yang tidak mendapatkan ASI Eksklusif disebabkan oleh karakteristik ibu diantaranya umur ibu yang terlalu muda sehingga tidak mengerti akan kebutuhan bayi, Pendidikan yang tidak memadai, pertama kali melahirkan sehingga tidak tahu pentingnya ASI Eksklusif, Pekerjaan, Mementingkan keindahan tubuh pasca persalinan, atau juga bisa disebabkan oleh kurangnya pengetahuan ibu disebabkan ibu tidak mendapatkan informasi dari pihak kesehatan, keluarga dan masyarakat. Faktor lain yang memperkuat ibu untuk tidak menyusui bayinya adalah pemakaian pil KB, gengsi supaya kelihatan lebih modern dan tidak kalah pentingnya adalah pengaruh iklan (Soetjiningsih, 1997).

Banyak penelitian yang membuktikan bahwa Air Susu Ibu (ASI) merupakan makanan terbaik dan utama bagi bayi, karena didalam ASI terkandung antibodi yang diperlukan bayi untuk melawan penyakitpenyakit yang menyerangnya. Pada dasarnya ASI adalah imunisasi pertama karena ASI mengandung berbagai zat kekebalan antara lain imunoglobin. Bayi yang tidak mendapat ASI beresiko terhadap infeksi saluran pernafasan seperti batuk, pilek, diare dan alergi (Soekirman, 2006).

Pada dasarnya saat ini banyak ibu yang memberikan pengganti ASI sebelum bayi berumur 6 bulan. Seharusnya pemberian ASI paling baik diberikan sampai umur 6 bulan tanpa tambahan makanan apapun. Jika dipaksa untuk mengonsumsi selain ASI tidak menutup kemungkinan bayi bisa sakit. Hal ini dapat mengakibatkan kekebalan bayi menurun (Kompas, 2007).

ASI sebagai makanan bayi mengandung laktosa, didalam usus laktosa akan di permentasi menjadi asam laktat yang bermanfaat sebagai zat antibodi, menghambat pertumbuhan bakteri bersifat pathogen, ASI tidak mengandung beta lactoglobulin yang dapat menyebabkan alergi (Arifin, 2004).

Berdasarkan data diatas peneliti tertarik untuk melakukan penelitian "Faktor - Faktor Yang Mempengaruhi Rendahnya Cakupan ASI EKSKLUSIF Pada Bayi Umur 0-6 Bulan di Bidan Praktik Salasiah Gun". Kenyataannya masih ada ibu yang tidak mengetahui pentingnya kandungan dari ASI EKSKLUSIF yaitu mengandung semua zat gizi yang diperlukan bayi dan di produksi khusus oleh tubuh ibu untuk bayinya. Untuk mengatasi masalah tersebut, pemerintah kesehatan harus membuat program-program yang dapat mendukung penggunaan ASI 
Eksklusif dengan memberikan pendidikan kesehatan tentang pentingnya pemberian ASI Eksklusif pada masyarakat.

\section{B. Rumusan Masalah}

Berdasarkan uraian latar belakang diatas maka dirumuskan masalahnya adalah: "Faktor - faktor apa saja yang mempengaruhi rendahnya cakupan ASI eksklusif pada bayi umur 0-6 bulan di Bidan Praktik Salasiah Gun Kecamatan Palaran Samarinda tahun 2017?".

\section{METODE PENELITIAN}

Jenis penelitian ini adalah kualitatif yang bersifat deskriptif. Metode penelitian deskriptif digunakan untuk memecahkan atau menjawab permasalahan yang sedang dihadapi pada situasi sekarang (Notoatmodjo, 2005).

Penelitian dilakukan di Bidan Praktik Salasiah Gun Kecamatan Palaran Samarinda tahun 2017. Penelitian ini dilakukan pada tanggal 18 April sampai dengan 07 Mei 2017.

Metode atau teknik sampling yang digunakan dalam penelitian ini adalah Non Probability sampling tipe (quota sampling). Tehnik Quota Sampling yaitu pengambilan sampel secara quota dilakukan dengan cara menetapkan sejumlah anggota sampel secara quotum atau jatah.

Dalam hal ini peneliti mengambil sampel 20\% dari populasi yang ada. Sehingga dapat diketahui jumlah sampel adalah 195 orang X 20\% = 39 orang.
Kriteria inklusi dalam penelitian ini adalah Ibu yang mempunyai bayi umur 0-6 bulan dan bersedia dilakukan penelitian di Bidan Praktik Salasiah Gun Kecamatan palaran Samarinda tahun 2017 dan Ibu yang mempunyai bayi umur 0-6 bulan dapat membaca dan menulis.

Sedangkan kriteria eksklusi dalam penelitian ini adalah Ibu yang menolak menjadi responden dan Ibu yang buta huruf.

Alat ukur dalam angket terdiri dari 2 bagian yaitu berisi identitas dan karakteristik responden meliputi nama ibu, umur, agama, dan alamat dan pengetahuan ibu tentang pemberian ASI Eksklusif yang meliputi gambaran pendidikan, pekerjaan dan Lingkungan.

Uji validitas dilakukan denganPearson Product Moment.Uji reliabilitas menggunakan rumus Spearman Brown.Dari hasil yang didapatkan setelah melakukan uji validitas dan reliabilitas dari 25 soal pernyataan dengan 20 responden di Bidan Praktik Swasta Saidatul Mardiah, Amd.Keb tenggarong seberang.

Maka didapatkan soal pernyataan yang valid dan reliable sebanyak 19 soal pernyataan. Dengan nilai $t$ hitung tertinggi adalah 4,04 dan nilai reliabel atau $r_{11}$ tertinggi 0,82 .

Analisa data dilakukan dengan cara mendeskripsikan hasil pengukuran faktorfaktor yang mempengaruhi rendahnya cakupan ASI Eksklusif di Bidan Praktik Salasiah Gun Kecamatan Palaran Samarinda tahun 2017. Analisa deskriptif di gunakan untuk menjabarkan sejumlah data guna 
memperoleh gambaran secara sistematis dan menyeluruh mengenai keadaan subyek penelitian.

\section{HASIL PENELITIAN}

\section{Karakteristik responden}

a. Umur

Tabel 1. Distribusi frekuensi berdasarkan umur ibu menyusui ASI Eksklusif di

Bidan Praktik Salasiah Gun Kecamatan

Palaran Samarinda tahun 2017.

\begin{tabular}{cccc}
\hline No. & Umur & Frekuensi & $\begin{array}{c}\text { Presentase } \\
(\%)\end{array}$ \\
\hline 1. & $\begin{array}{c}20-25 \\
\text { tahun }\end{array}$ & 14 & 35,9 \\
\hline 2. & $\begin{array}{c}26-35 \\
\text { tahun }\end{array}$ & 22 & 56,4 \\
\hline $3 . \quad 36$ \\
tahun
\end{tabular}

b. Agama

Tabel 2 Distribusi frekuensi berdasarkan agama ibu menyusui ASI Eksklusif di

Bidan Praktik Salasiah Gun Kecamatan

Palaran Samarinda tahun 2017.

\begin{tabular}{|c|c|c|c|}
\hline No. & Agama & Frekuensi & $\begin{array}{c}\text { Persentase } \\
(\%)\end{array}$ \\
\hline 1. & Islam & 36 & 92,3 \\
\hline \multirow[t]{2}{*}{2.} & Kristen & 3 & 7,7 \\
\hline & Jumlah & 39 & 100 \\
\hline & erdasarkan & tabel & diatas bahwa \\
\hline & sponden & terbanyak & adalah yang \\
\hline
\end{tabular}

c. Pendidikan
Tabel 3 Distribusi frekuensi

berdasarkan pendidikan ibu menyusui ASI Eksklusif di Bidan Praktik

Salasiah Gun Kecamatan Palaran

Samarinda tahun 2017.

\begin{tabular}{cccc}
\hline No & Pendidikan & Frekuensi & $\begin{array}{c}\text { Persentase } \\
(\%)\end{array}$ \\
\hline 1. & SD & 5 & 12,8 \\
\hline 2. & SMP & 14 & 35,9 \\
\hline 3. & SMA & 18 & 46,2 \\
\hline 4. & $\begin{array}{c}\text { PT } \\
\text { (Perguruan } \\
\text { Tinggi) }\end{array}$ & 2 & 5,1 \\
\hline & Jumlah & 39 & 100 \\
\hline & Berdasarkan tabel diatas bahwa \\
& pendidikan responden terbanyak \\
& adalah lulusan SMA sebanyak 18 \\
& responden (46,2\%).
\end{tabular}

d. Pekerjaan

Tabel 4 Distribusi frekuensi

berdasarkan pekerjaan ibu menyusui ASI Eksklusif di Bidan Praktik

Salasiah Gun Kecamatan Palaran Samarinda tahun 2017.

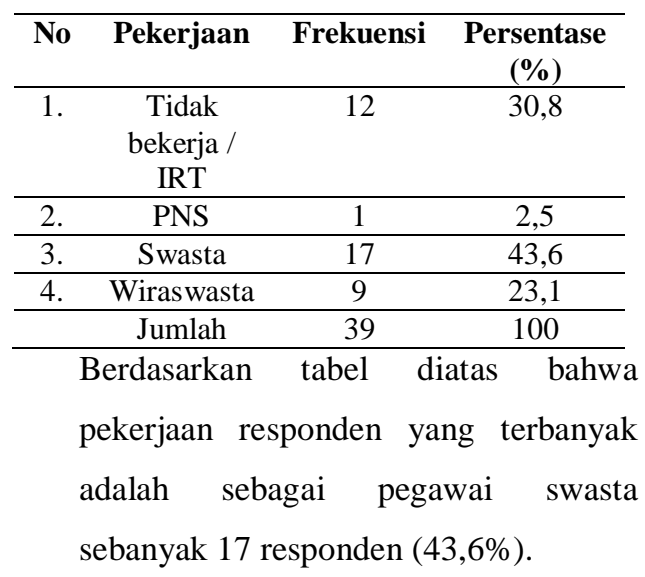

\section{Analisis Univariat}

Tujuan Analisa ini adalah untuk menjelaskan/mendeskripsikan karakteristik masing-masing variabel yang diteliti.

a. Pengetahuan ibu dalam Pemberian ASI Eksklusif 
Variabel terikat dalam penelitian ini adalah ibu yang memberikan ASI Eksklusif, berdasarkan hasil kuesioner (angket) diperoleh distribusi frekuensi berdasarkan kategori sebagai berikut :

Tabel 5. Distribusi Frekuensi berdasarkan Pengetahuan ibu dalam pemberian ASI Eksklusif pada bayi umur 0-6 bulan di Bidan Praktik Salasiah Gun Kecamatan Palaran Samarinda tahun 2017.

\begin{tabular}{cccc}
\hline No & $\begin{array}{c}\text { Pemberian } \\
\text { ASI } \\
\text { Eksklusif }\end{array}$ & Frekuensi & $\begin{array}{c}\text { Persentase } \\
(\%)\end{array}$ \\
\hline 1. & Baik & 7 & 17,9 \\
\hline 2. & Cukup & 11 & 28,2 \\
\hline 3. & Kurang & 21 & 53,9 \\
\hline & Jumlah & 39 & 100 \\
\hline Berdasarkan & tabel diatas & dapat
\end{tabular}
disimpulkan bahwa responden yang mempunyai pengetahuan baik terhadap pemberian ASI Eksklusif sebanyak 7 orang $(17,9 \%)$ dan yang mempunyai pengetahuan cukup terhadap pemberian ASI Eksklusif sebanyak 11 orang $(28,2 \%)$ sedangkan responden yang mempunyai pengetahuan kurang terhadap pemberian ASI Eksklusif sebanyak 21 orang $(53,9 \%)$.

b. Dari segi pendidikan

Tabel 6. Distribusi Frekuensi berdasarkan dari segi pendidikan di Bidan Praktik Salasiah Gun Kecamatan

Palaran Samarinda tahun 2017.

\begin{tabular}{|c|c|c|c|}
\hline No & Pendidikan & Frekuensi & $\begin{array}{c}\text { Persentase } \\
(\%)\end{array}$ \\
\hline 1. & Tinggi & 2 & 5 \\
\hline \multirow[t]{2}{*}{2.} & Rendah & 37 & 95 \\
\hline & Jumlah & 39 & 100 \\
\hline & erdasarkan & tabel diata & dapat \\
\hline
\end{tabular}

2 orang (5\%) dan yang mempunyai pendidikan rendah sebanyak 37 orang $(95 \%)$.

c. Dari segi pekerjaan

Tabel 7. Distribusi frekuensi berdasarkan dari segi pekerjaan di

Bidan Praktik Salasiah Gun

Kecamatan Palaran Samarinda tahun 2017.

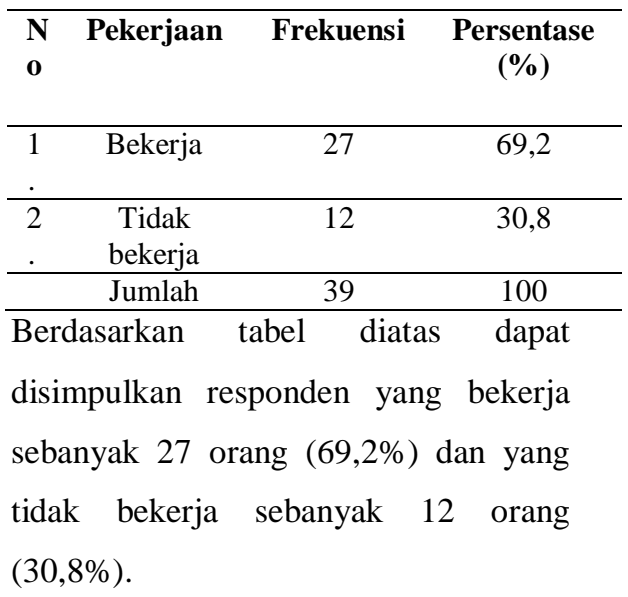

d. Dari segi lingkungan

Tabel 8. Distribusi Frekuensi

berdasarkan dari segi lingkungan di

Bidan Praktik Salasiah Gun

Kecamatan Palaran Samarinda Tahun 2017.

\begin{tabular}{|c|c|c|c|}
\hline No & Lingkungan & Frekuensi & $\begin{array}{c}\text { Persentase } \\
(\%)\end{array}$ \\
\hline 1. & Mendukung & 6 & 15,4 \\
\hline 2. & $\begin{array}{c}\text { Tidak } \\
\text { Mendukung }\end{array}$ & 33 & 84,6 \\
\hline & Jumlah & 39 & 100 \\
\hline
\end{tabular}
disimpulkan bahwa responden yang mendukung dari segi lingkungan sebanyak 6 orang $(15,4 \%)$ dan yang tidak mendukung dari segi lingkungan sebanyak 33 orang $(84,6 \%)$.

\section{PEMBAHASAN}


a. Pengetahuan ibu dalam pemberian ASI

Eksklusif

Berdasarkan Hasil penelitian menunjukkan bahwa responden yang mempunyai pengetahuan baik terhadap pemberian ASI Eksklusif sebanyak 7 orang $(17,9 \%)$ dan yang mempunyai pengetahuan cukup terhadap pemberian ASI Eksklusif sebanyak 11 orang $(28,2 \%)$ sedangkan responden yang mempunyai pengetahuan kurang terhadap pemberian ASI Eksklusif sebanyak 21 orang $(53,9 \%)$, dari hasil perhitungan ini menunjukkan bahwa pengetahuan ibu terhadap pemberian ASI Eksklusif masih kurang.

Penyebab menurunnya pemberian ASI eksklusif adalah kurangnya pengetahuan ibu tentang pentingnya pemberian ASI eksklusif dan adanya pemasaran susu formula. Selain itu juga masih banyak masyarakat yang suka memberi MP-ASI terlalu dini (Agnes, 2007).

b. Dari segi pendidikan

Berdasarkan hasil penelitian menunjukkan bahwa responden yang mempunyai pendidikan tinggi sebanyak 2 orang $(5 \%)$ dan yang mempunyai pendidikan rendah sebanyak 37 orang (95\%).

Dari hasil perhitungan ini menunjukkan bahwa dari segi pendidikan dapat mempengaruhi ibu dalam memberikan ASI Eksklusif karena banyak ibu yang berpendidikan rendah dan tidak mampu mengatasi masalah-masalah yang dihadapi dalam kehidupan sehari-hari tetapi ada sebagian ibu yang berpendidikan tinggi lebih memilih kesibukan diluar rumah sehingga mereka memilih memberikan makanan pendamping ASI pada bayi mereka dibanding menyusui karena takut akan merusak kecantikan.

Menurut John Dewey (1997), mengatakan bahwa melalui pendidikan seseorang akan mempunyai kesiapan, mental dan emosional yang membantu seseorang untuk dapat berkembang mencapai tingkat kedewasaan. Dalam teori ini tingkat pendidikan seseorang sangat mempengaruhi semua aktifitas yang dilakukannya. Hal ini disebabkan karena dalam proses pendidikan terjadi perubahan kesiapan, mental dan emosional kearah tingkat kedewasaan yang lebih tinggi.

\section{c. Dari segi Pekerjaan.}

Berdasarkan hasil penelitian menunjukkan bahwa responden yang bekerja sebanyak 27 orang $(69,2 \%)$ dan responden yang tidak bekerja sebanyak 12 orang $(30,8 \%)$.

Dari hasil perhitungan ini menunjukkan bahwa pemberian ASI Eksklusif terhadap segi pekerjaan masih rendah karena banyak ibu yang masih bekerja sebanyak 27 orang $(69,2 \%)$ sehingga mereka tidak mempunyai kesempatan dalam memberikan ASI Eksklusif kepada bayinya. Dan mereka beranggapan akan memberikan susu formula kepada bayinya disaat mereka bekerja. 
Selain itu pengertian pekerjaan sendiri adalah Pekerjaan merupakan suatu kegiatan atau aktivitas seseorang untuk memperoleh penghasilan guna memenuhi kebutuhan hidup sehari-hari (Notoatmodjo, 2003).

Hal ini sesuai dengan teori Pudjiadi (1997), bahwa bekerja adalah suatu alasan ibu memberikan makanan pendamping ASI pada bayinya, dengan bekerja biasanya ibu sibuk, aktif dalam bisnis, bekerja sebagai pegawai perusahaan, atau melakukan banyak pekerjaan sosial sehingga ibu tidak bisa memberikan ASI Eksklusif. Menurut Soetjiningsih (1997), bahwa banyak faktor yang menyebabkan penurunan ASI ini karena banyak ibu-ibu yang ikut bekerja untuk mencari nafkah, sehingga tidak dapat menyusui bayinya dengan baik.

d. Dari segi lingkungan

Berdasarkan hasil penelitian menunjukkan bahwa responden yang mendukung dari segi lingkungan sebanyak 6 orang $(15,4 \%)$ dan yang tidak mendukung dari segi lingkungan sebanyak 33 orang $(84,6 \%)$. Dari hasil perhitungan ini menunjukkan bahwa lingkungan berpengaruh dalam pemberian ASI Eksklusif karena lebih banyak lingkungan yang tidak mendukung. Dan ibu masih mudah terpengaruh oleh hal-hal sekitar dan yang dianggap modern serta ibu masih gengsi untuk menyusui bayinya ketika berpergian.

Karena lingkungan adalah
seluruh kondisi yang ada di sekitar

manusia dan pengaruhnya dapat mempengaruhi perkembangan dan perilaku orang atau kelompok. Menurut Ann Manner (1998), lingkungan memberikan pengaruh sosial pertama bagi seseorang dimana seseorang dapat mempelajari hal-hal yang baik dan juga hal-hal yang buruk tergantung pada sifat kelompok dalam lingkungan alam.

Hal ini sesuai dengan teori Notoatmodjo (2003), bahwa perilaku kesehatan individu yaitu sikap dan kebiasaan individu yang erat kaitannya dengan lingkungan. Lingkungan keluarga yaitu kebiasaan-kebiasaan tiap anggota keluarga mengenai kesehatan. Lingkungan terbatas yaitu tradisi, adatistiadat, dan kepercayaan masyarakat sehubungan dengan kesehatan.

\section{KESIMPULAN}

Berdasarkan penelitian yang dilakukan tahun 2017didapatkanhasil sebagai berikut:

1. Pengetahuan ibu terhadap pemberian ASI Eksklusif masih kurang sebanyak 21 orang $(53,9 \%)$, hal ini disebabkan karena kurangnya pengetahuan ibu tentang pentingnya pemberian ASI eksklusif dan adanya pemasaran susu formula. Selain itu juga masih banyak masyarakat yang suka memberi MP-ASI terlalu dini. Seharusnya pemberian ASI paling baik diberikan sampai umur 6 bulan tanpa tambahan makanan apapun.

2. Dari segi pendidikan dapat mempengaruhi ibu dalam memberikan ASI Eksklusif. Hal ini disebabkan karena banyak ibu 
yang berpendidikan rendah sebanyak 37 orang $(95 \%)$ dan tidak mampu mengatasi masalah-masalah yang dihadapi dalam kehidupan sehari-hari.

3. Dari segi pekerjaan masih banyak ibu yang bekerja sebanyak 27 orang $(69,2 \%)$ sehingga mereka tidak mempunyai kesempatan dalam memberikan ASI Eksklusif kepada bayinya. Dan mereka beranggapan akan memberikan susu formula kepada bayinya disaat mereka bekerja.

4. Dari segi lingkungan, lingkungan berpengaruh dalam pemberian ASI Eksklusif karena lebih banyak lingkungan yang tidak mendukung sebanyak 33 orang $(84,6 \%)$. Dan ibu masih mudah terpengaruh oleh hal-hal sekitar dan yang dianggap modern serta ibu masih gengsi untuk menyusui bayinya ketika berpergian.

\section{DAFTAR PUSTAKA}

Arikunto. 2006. Prosedur Penelitian Suatu Pendekatan Praktik. Jakarta : Rineka cipta.

Arief, T. 2008. Kesehatan ibu Hamil dan Ibu Melahirkan. Jakarta : EGC

Dep. Kes. Bud. RI. 2001. Kamus Besar Bahasa Indonesia. Jakarta : Balai Pustaka.

Hanton, TW. 2001. Panduan Senam Kebugaran Untuk Wanita Hamil. Jakarta : PT Raja Grafindo Persada.

Hidayah, A. 2007. Metode Penelitian Kebidanan Dan Teknik Analisis Data. Jakarta : Salemba Medika.
Irmayanti. 2007. Pengetahuan. Available on line : http :// www.Wikipedia.org / wiki /pengetahuan, Diakses tanggal 19 Maret 2011

Mandriwati, G A. 2008. Penuntun Belajar Asuhan Ibu Hamil. Jakarta: EGC.

Mansjoer, A. DKK. 2001. Kapita Selekta Kedokteran. Fakultas Kedokteran Universitas Indonesia : Media Aesculapius.

Maureen, B. 2005. Mempersiapkan Kelahiran Bayi Anda. Jakarta : EGC.

Mellyna, H. 2002. Panduan Menjalani Kehamilan Sehat. Jakarta : Puspa Swara.

Mochtar, R. 1998. Sinopsis Obstetri. Jakarta : EGC.

Muhimah, 2010. Мепији Kelahiran Yang Alami. Jakarta: PT. Raja Grafindo Persada

Notoadmojo, Soekidjo. 2002. Metodologi Penelitian Kesehatan. Jakarta : PT. Rineka Cipta.

Notoadmojo, Soekidjo. 2003. Ilmu Kesehatan Massyarakat. Jakarta : PT. Rineka Cipta.

Notoatmojo, Soekidjo. 2005. Metodologi Penelitian Kesehatan. Jakarta : PT. Rineka Cipta

Notoatmodjo, S. 2010.Metodologi Penelitian Kesehatan. Jakarta : Rineka Cipta.

Poppy, A. 2010. Serba - serbi Senam Hamil. Yogyakarta : Intan Media

Prawirohardjo, S. 2005. Ilmu Kebidanan. Jakarta : Yayasan Bina Pustaka.

Savitri, R. 2005. Gaya Hidup di Masa Hamil. Jakarta : Buana Ilmu Populer . 
JURNAL KEBIDANAN MUTIARA MAHAKAM, VOLUME VI, NOMOR 2, SEPTEMBER 2018

Varney, Helen. 2007. Asuhan Kebidanan

Edisi 4 Volume 1. EGC. Jakarta

Yuliarti, N. 2010. Panduan Lengkap

Olahraga Bagi Wanita Hamil dan

Menyusui. Yogyakarta : Andi Offset. 